\title{
The Expression and Localization of Neutral Endopeptidase 24.11/CD10 in Human Gestational Trophoblastic Diseases
}

\author{
Kazuhiko Ino, Takahiro Suzuki, Carlos Uehara, Tetsuro Nagasaka, \\ Tomomitsu Okamoto, Fumitaka Kikkawa, and Shigehiko Mizutani \\ Department of Obstetrics and Gynecology (KI, TS, CU, TO, FK, SM), and Division of Pathology, Clinical Laboratory \\ (TN), Nagoya University School of Medicine, Nagoya, Japan
}

SUMMARY: Neutral endopeptidase 24.11 (NEP)/CD10 is a cell-surface peptidase that hydrolyzes various bioactive peptides. NEP is distributed in both normal and neoplastic cells and plays a functional role by modulating cellular responses to peptide substrates. Recently, NEP has been shown to be expressed in normal placental trophoblasts, suggesting its physiological role during pregnancy. In the present study, we investigated the expression of NEP in hyperplastic and anaplastic trophoblasts in gestational trophoblastic diseases (GTDs). Flow cytometric analysis demonstrated that NEP was expressed in all choriocarcinoma cell lines examined. The NEP enzyme activity in these cell lines correlated with cell-surface protein levels and was abolished by the NEP inhibitor phosphoramidon. On immunoblot analysis, NEP protein was detected in both hydatidiform mole and choriocarcinoma tissues as a double band of 95 and $100 \mathrm{kDa}$ similar to that of the normal placental tissues. Immunohistochemical analysis revealed that NEP was present on syncytiotrophoblasts, while no or very faint NEP immunoreactivity was observed on cytotrophoblasts in the normal placenta. Similarly, NEP in hydatidiform mole and invasive mole was localized on the membrane of syncytiotrophoblasts, but not on hyperplastic cytotrophoblasts. In contrast, in choriocarcinoma, NEP was highly expressed not only on syncytiotrophoblastic cells but also on invading anaplastic cytotrophoblasts. In addition, NEP was also expressed on intermediate trophoblasts in placental site trophoblastic tumors. In summary, this is the first study demonstrating the expression of NEP/CD10 in GTDs. The differential localization of NEP among various trophoblastic tumors suggests that NEP may play a functional role in the regulation of trophoblast transformation and human chorionic gonadotropin secretion. (Lab Invest 2000, 80: 1729-1738).

\begin{abstract}
Cestational trophoblastic diseases (GTDs), un$G$ usual tumors arising from the trophoblast, are comprised of a spectrum of disease of hydatidiform mole, invasive mole, choriocarcinoma, and placental site trophoblastic tumor (PSTT) (Mazur and Kurman, 1987; Shih et al, 1999). Although GTDs are known to exhibit excessive trophoblast proliferation and secrete various levels of human chorionic gonadotropin (hCG) (Shih et al, 1999), the regulatory mechanisms responsible for these phenomena are still unclear. Recently, we have demonstrated that both aminopeptidase $\mathrm{N}$ (APN) and aminopeptidase A (APA) are highly expressed on choriocarcinoma cells, and these cellsurface peptidases are involved in the proliferation, differentiation, and hCG secretion of neoplastic trophoblasts (Ino et al, 1994, 2000).
\end{abstract}

Received July 13, 2000.

This work was supported in part by grant-in-aid No.11770934 (to KI) from the Japanese Ministry of Education, Science and Culture, and also by grant-in-aid for Specific Medical Research (to Nagoya Teishin Hospital) from the Japanese Ministry of Posts and Telecommunications.

Address reprint requests to: Dr. Kazuhiko Ino, Department of Obstetrics and Gynecology, Nagoya University School of Medicine, 65 Tsurumai-cho, Showa-ku, Nagoya 466-8550, Japan. Fax: 8152744 2268; E-mail: kazuino@tsuru.med.nagoya-u.ac.jp
Neutral endopeptidase 24.11 (NEP, neprilysin, enkephalinase, EC 3.4.24.11) is also a membrane-bound metallopeptidase that regulates the biological activities of peptide substrates by reducing the local concentrations available for receptor binding and signal transduction (Shipp and Look, 1993). The human NEP has been cloned and is identical to CD10 (Malfroy et al, 1988; Shipp et al, 1989), which is expressed on lymphoid progenitors, neutrophils and in some lymphoid malignancies. However, the enzyme is also expressed on a variety of nonhematopoietic cells and certain solid tumor cell lines (Chu and Arber, 2000). Because NEP cleaves small peptides on the aminoterminal side of hydrophobic amino acids, there are many known NEP substrates including enkephalins, atrial natriuretic factor, substance $P$, bombesin, and endothelins (Erdös and Skidgel, 1989). The physiological role of the enzyme depends on available substrates in specific organs and cell types (Shipp and Look, 1993). The enzyme also regulates peptidemediated cellular proliferation by inactivating bombesin or other neuropeptides that are essential autocrine growth factors for certain human solid tumors (Burns et al, 1999; Cohen et al, 1996; Papandreou et al, 1998; Shipp et al, 1991).

Recent investigations have shown that NEP is expressed in normal human placental trophoblasts and 
could be involved in the regulation of the local concentrations of circulating biologically active peptides at the feto-maternal interface, and thus may be involved in pathophysiological changes during pregnancy (Imai et al, 1994; Johnson et al, 1984; Li et al, 1995). Although the in vivo substrate of NEP expressed by trophoblasts has not yet been identified, NEP may hydrolyze and modulate several specific peptide factors related to trophoblast functions such as endothelin-1 (ET-1) (Vijayaraghavan et al, 1990) and gonadotropin-releasing hormone $(\mathrm{GnRH})$ (Flouret et al, 1987; Medeiros et al, 1991), which may contribute to the regulation of growth, differentiation, and hCG secretion of the trophoblasts.

The above findings prompted us to investigate the expression of NEP/CD10 in GTDs that contain hyperplastic and anaplastic trophoblasts. We report here the differential NEP expression and localization among these tumors and discuss the possible role of this enzyme in neoplastic trophoblast function by modulating specific bioactive peptides.

\section{Results}

\section{Expression and Enzymatic Activity of NEP in Choriocarcinoma Cell Lines}

Cell-surface levels of NEP/CD10 on four gestational choriocarcinoma cell lines were estimated by FACS analysis using the NEP/CD10-specific mAb. As shown in Figure 1, NaUCC-1 and NaUCC-3 expressed moderate levels of NEP, and NaUCC-4 expressed the highest level. In contrast, BeWo showed a low level of NEP expression.

NEP enzyme activity in these choriocarcinoma cell lines was examined by assessing the hydrolysis of succinyl-Ala-Ala-Phe-p-nitroanilide in coupled enzyme assay as described in the "Materials and Methods" section. As shown in Figure 2, the high NEPexpressing cell line NaUCC-4 exhibited a high level of enzyme activity, whereas NaUCC-1 and NaUCC-3 showed moderate activity, and BeWo had minimal
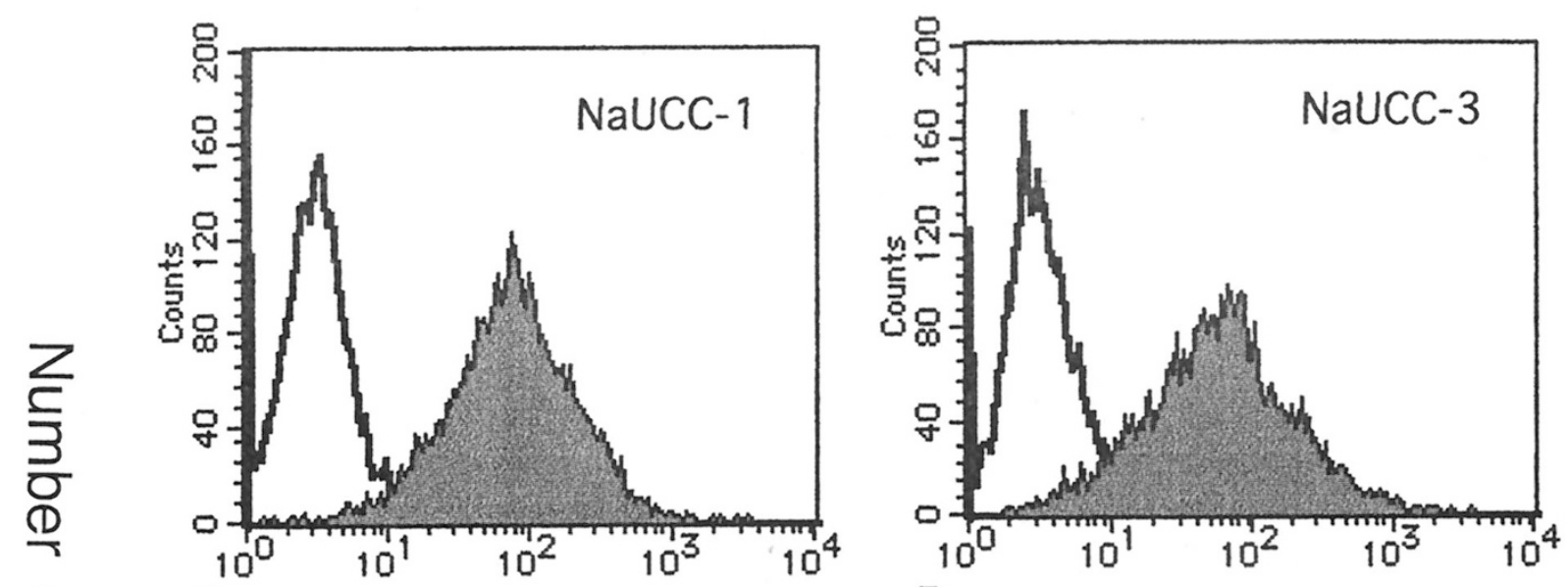

$\frac{O}{\infty}$
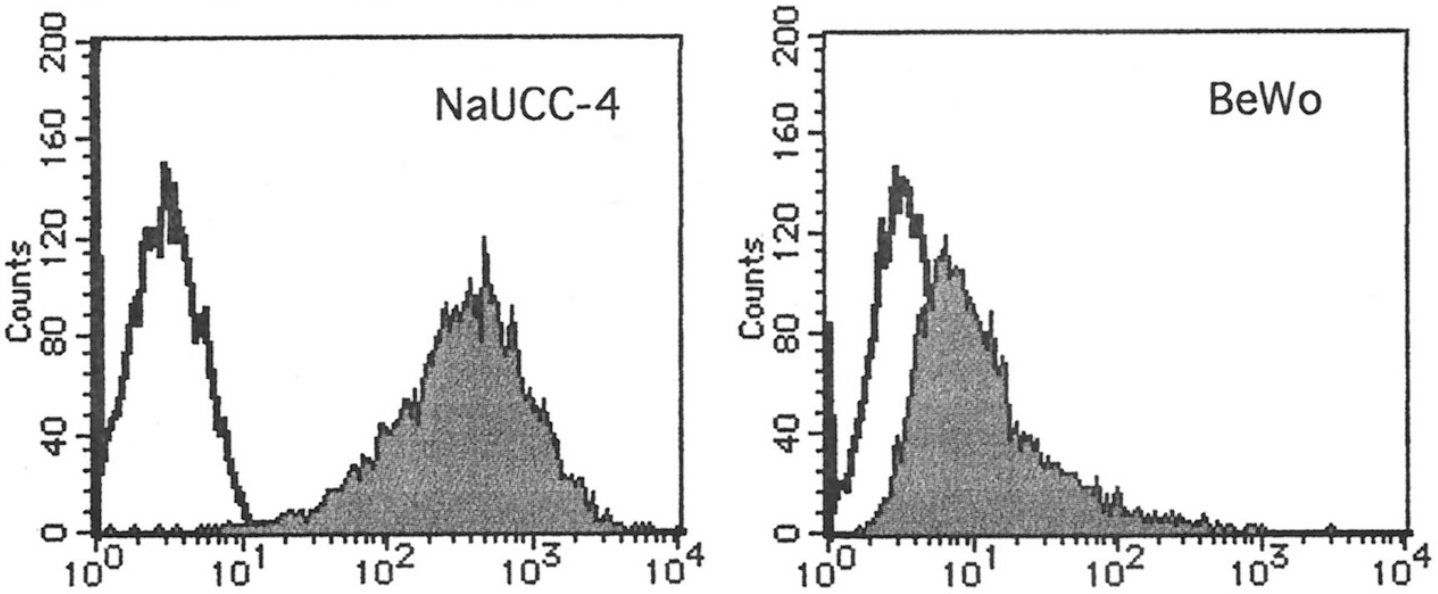

\section{Log Fluorescence Intensity}

Figure 1.

Cell-surface expression of NEP/CD10 on choriocarcinoma cell lines. Cells were stained with the PE-labeled NEP/CD10-specific mouse mAb (shaded area) or PE-labeled isotype-matched mouse IgG (open area). FACS analysis was performed on NaUCC-1 (upper left), NaUCC-3 (upper right), NaUCC-4 (lower left), and BeWo (lower right) cells. Mean fluorescence intensity (MFI) values were 111.84 in NaUCC-1, 84.22 in NaUCC-3, 476.73 in NaUCC-4, and 12.24 in BeWo. The MFI value using control mouse IgG was less than 4.0 in all cell lines. 
enzyme activity. These results demonstrated that the cell-surface expression levels of NEP were correlated with enzymatic activity. The NEP activity in these cell lines was completely inhibited by pretreatment with 2 $\mu \mathrm{M}$ phosphoramidon, a specific inhibitor of NEP (Fig. 2 ), indicating that the enzyme activity detected was NEP and not a related endopeptidase.

\section{Immunoblot Analysis for NEP Protein Expression}

Immunoblot analysis was performed using the mouse anti-NEP/CD10 mAb to detect NEP protein expression in trophoblastic tumor cell lines and tissues. NEP protein was detected as a double band with molecular weights of approximately 95 and $100 \mathrm{kDa}$ in the normal placentas used as positive controls (Fig. 3). The choriocarcinoma cell lines NaUCC-1 and NaUCC-4 showed abundant NEP protein expression as similar double bands, whereas NaUCC-3 and BeWo showed lower NEP expression with a single band of $100 \mathrm{kDa}$ (Fig. 3).

Tissue samples of three uterine choriocarcinomas and two hydatidiform moles were also examined for NEP expression by immunoblot analysis. As shown in Figure 3, NEP protein was detected in both hydatidiform mole and choriocarcinoma as a double band similar to that in the normal placenta.

\section{Immunohistochemical Localization of NEP in GTD Tissues}

To confirm NEP localization in GTDs, immunohistochemical stainings of formalin-fixed, paraffinembedded tissue sections including six hydatidiform mole, four invasive mole, eight choriocarcinoma, and two PSTT were conducted using the anti-NEP/CD10 $m A b$. First, we examined NEP immunoreactivity in the normal placenta as a positive control. As shown in Figure 4A, NEP was localized to the syncytiotrophoblast layer of the normal term placenta, consistent with the results of previous reports (Imai et al, 1994; Li et al, 1995; Mclntosh et al, 1999). In this section, no NEP immunoreactivity was observed in the stromal cells or fetal vessels of the placental villi.

In hydatidiform mole, NEP immunoreactivity was detected on the membrane of syncytiotrophoblasts, but not on cytotrophoblasts (Fig. 4B). Similarly, marked NEP expression was observed on syncytiotrophoblasts, but not on hyperplastic cytotrophoblasts in invasive mole that has moderate proliferative potential between those of hydatidiform mole and choriocarcinoma (Fig. 4C). In the noninvasive lesions of uterine choriocarcinoma, NEP was also mainly localized on the cell membrane of syncytiotrophoblastic choriocarcinoma cells that were giant, multinucleated cells with fusiform, dense cytoplasm (Fig. 5A). In contrast, in the

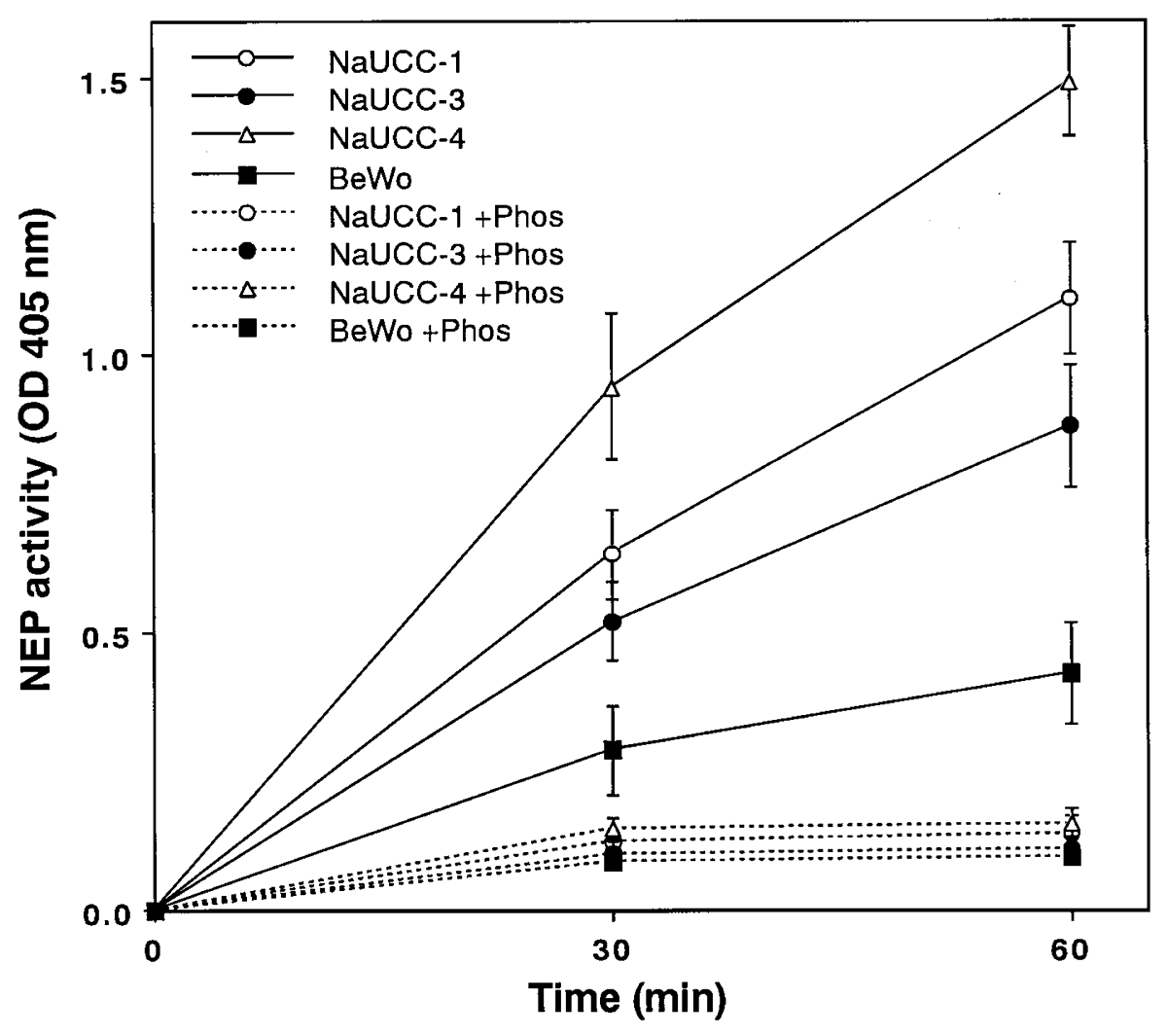

Figure 2.

NEP enzymatic activity in choriocarcinoma cell lines. Cells were incubated at $37^{\circ} \mathrm{C}$ in a substrate solution containing $1 \mathrm{~mm}$ Suc-Ala-Ala-Phe-pNA in the presence of porcine kidney AP-N, and optical density of the supernatant at $405 \mathrm{~nm}$ was measured with a spectrophotometer at appropriate time points. NEP activity was abrogated in all cell lines by treatment with the NEP inhibitor phosphoramidon (+Phos) at $2 \mu \mathrm{M}$. Each point and bar represent the mean and SD of three experiments. 


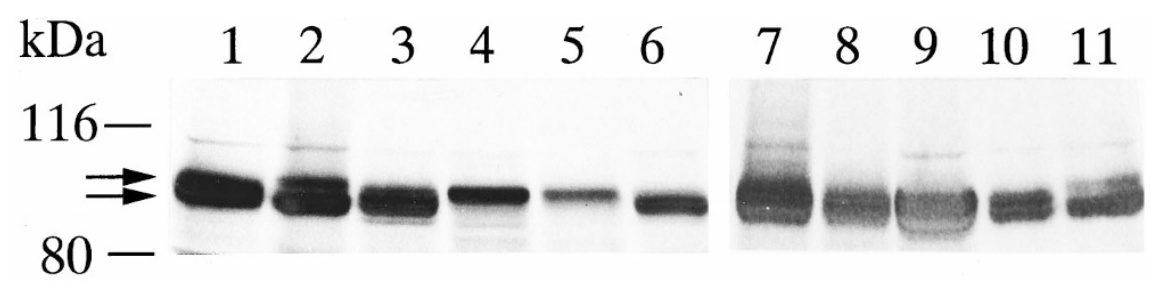

Figure 3 .

Immunoblot analysis of NEP/CD10 using mouse anti-NEP mAb. Proteins (30 $\mu \mathrm{g})$ extracted from normal placental tissues (lanes 1 and 2), choriocarcinoma cell lines (lanes 3 to 6), and trophoblastic tumor tissues (lanes 7 to 11) were separated on SDS/7.5\% polyacrylamide gels and electroblotted onto nitrocellulose membranes. NEP protein (arrows) was detected as a double band with molecular weights of approximately 95 and 100 kDa with the exception of two choriocarcinoma cell lines (lanes 4 and 5) that showed a single band of approximately $100 \mathrm{kDa}$. Lane 1, first trimester chorionic villi; lane 2, term placenta; lane 3, NaUCC-4; lane 4, NaUCC-3; lane 5, BeWo; lane 6, NaUCC-1; lanes 7 to 9, three different choriocarcinoma tissues; lanes 10 and 11 , two different hydatidiform mole tissues.

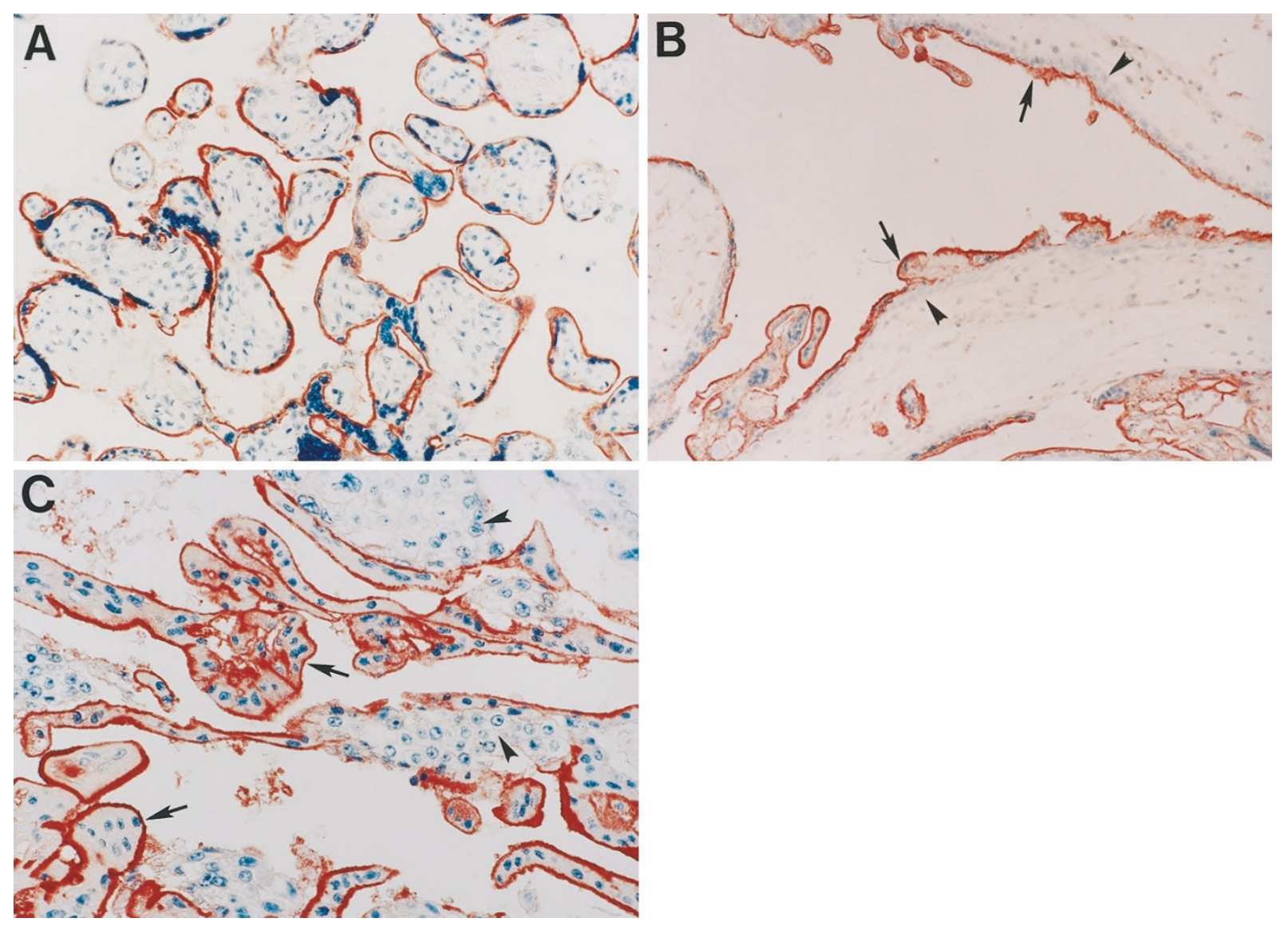

Figure 4.

Immunohistochemical localization of NEP/CD10 using anti-NEP mAb. A, Normal term placenta. Note staining in the syncytiotrophoblast layer and general absence of staining in the stromal cells and fetal vessels of the placental villi (original magnification, $\times 100$ ). $B$, Complete hydatidiform mole. Syncytiotrophoblasts showed positive staining (arrows) in contrast to the complete absence of staining on cytotrophoblasts (arrowheads) (original magnification, $\times 100$ ). C, Invasive mole invading the uterine myometrium. Note intense staining on the membranes of syncytiotrophoblasts (arrows) and absence of staining on hyperplastic cytotrophoblasts (arrowheads) (original magnification, $\times 200)$.

sections of myometrial invasion of choriocarcinoma, NEP was not only highly expressed on syncytiotrophoblastic cells, but also diffusely detected on invading anaplastic cytotrophoblasts that were highly proliferative and mononucleated (Fig. 5, B and C). In addition, no NEP immunoreactivity was observed in adjacent myometrial smooth muscle or stromal cells.

Finally, two PSTT cases, including one primary uterine lesion and one lung metastasis, were examined for NEP expression and localization. As shown in Figure 6, NEP was diffusely and moderately expressed on infiltrating tumor cells with the features of PSTTspecific intermediate trophoblast in a lung metastatic lesion derived from PSTT. Similar positive staining for NEP was observed in a section of primary uterine PSTT (data not shown).

\section{Discussion}

The present results of immunohistochemical analyses demonstrated that NEP/CD10 was mainly localized to syncytiotrophoblasts in the normal term placenta. Our 

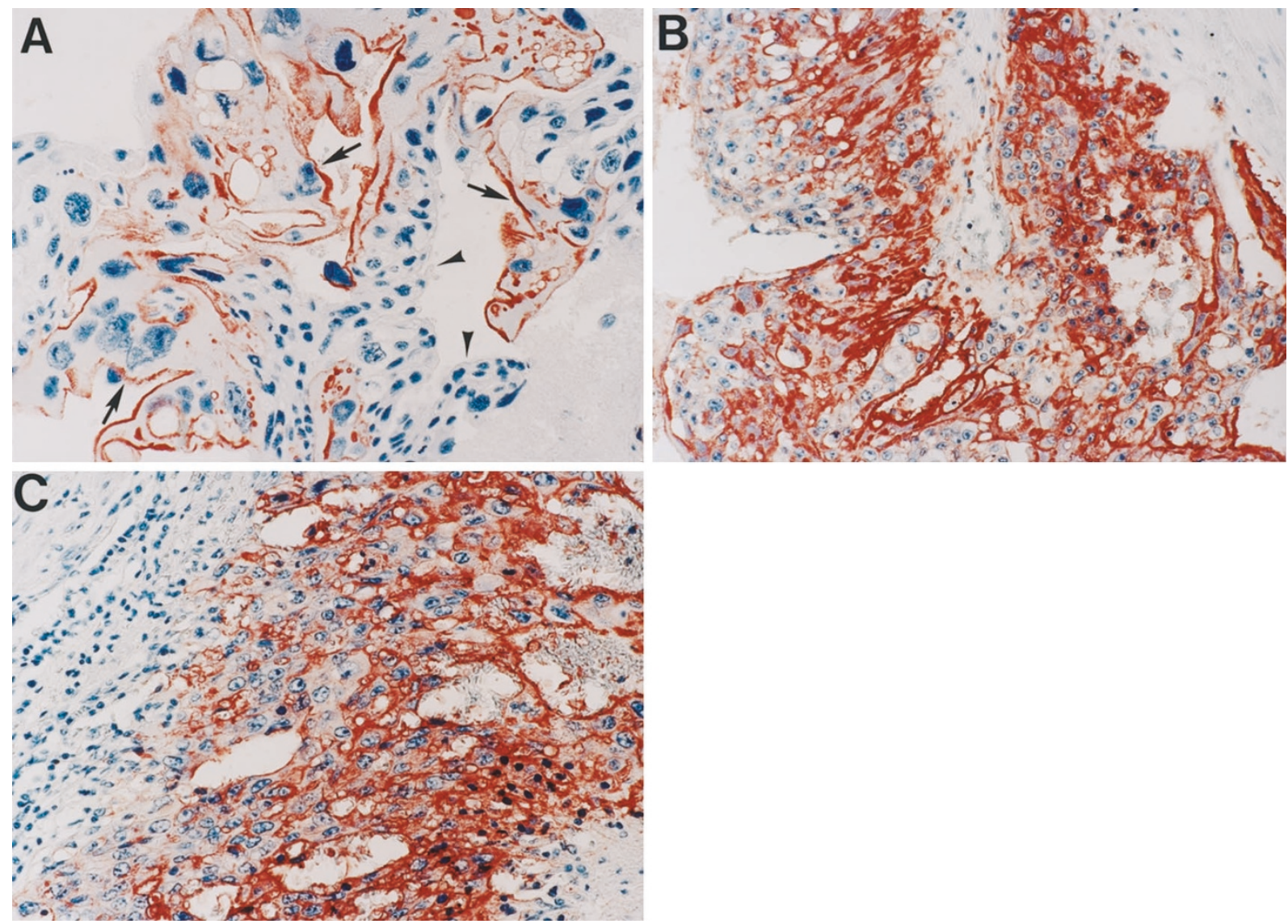

Figure 5.

Immunohistochemical staining of NEP/CD10 in gestational choriocarcinoma tissues. A, Noninvasive lesion of uterine choriocarcinoma. NEP was localized to the cell membrane of syncytiotrophoblastic cells (arrows) and lacked NEP expression in cytotrophoblastic cells (arrowheads) (original magnification, $\times 200$ ). $B$ and $C$ Choriocarcinoma invading the uterine myometrium. Note intense membrane staining on both anaplastic syncytiotrophoblasts and cytotrophoblasts (original magnification: $B, \times 160 ; C, \times 200)$.
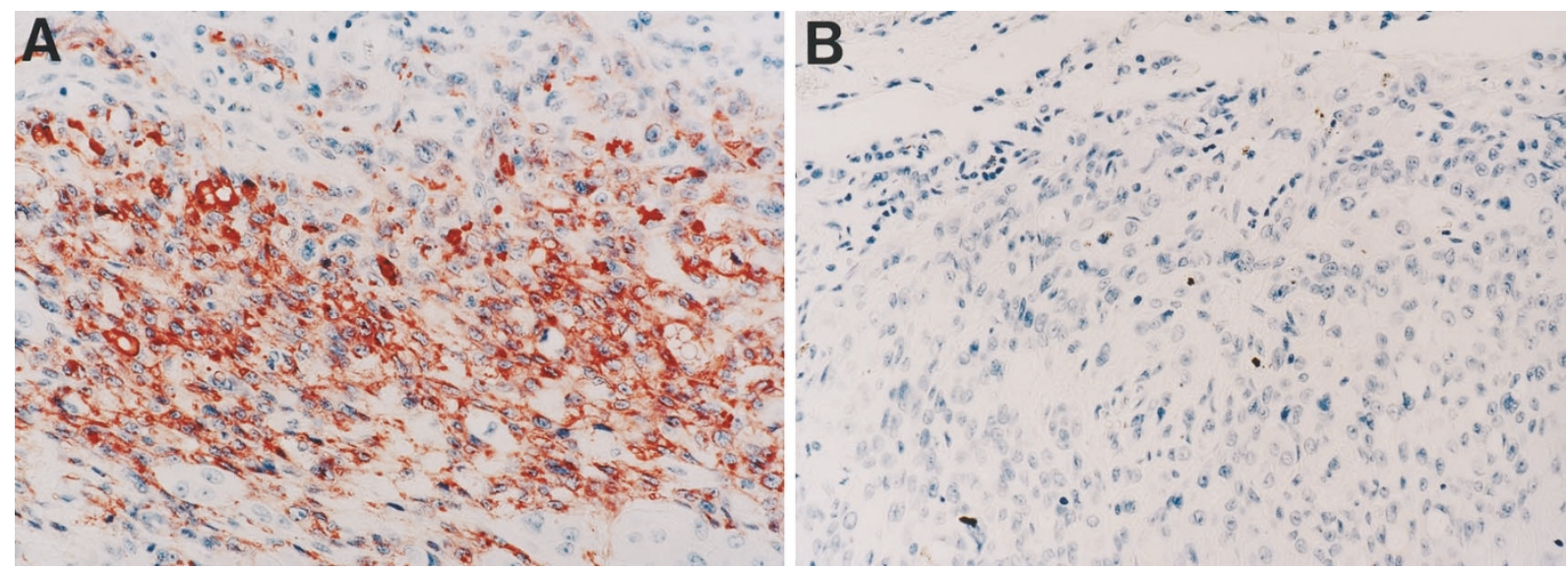

\section{Figure 6.}

Immunohistochemical staining of NEP/CD10 in placental site trophoblastic tumor (PSTT). A, Diffuse positive staining in intermediate-type trophoblasts with anti-NEP $\mathrm{mAb}$ (original magnification, $\times 200$ ). $B$, Negative control staining with normal mouse IgG (original magnification, $\times 200$ ).

additional experiments using normal placental tissues obtained at different gestational weeks showed that NEP was present on syncytiotrophoblasts throughout pregnancy, but was weakly or faintly expressed on cytotrophoblasts in the first and second trimester chorionic villi (unpublished data), which is well consis- tent with other reports (Imai et al, 1994; McIntosh et al, 1999). A variety of active peptides are known to be NEP substrates in vitro (Erdös and Skidgel, 1989). It has been shown that NEP regulates the biological activity of the peptide substrates in vivo by modulating their local concentrations available for receptor bind- 
ing and signal transduction (Shipp and Look, 1993). Li et al (1995) demonstrated that NEP was expressed in human placental trophoblasts and could be involved in the regulation of circulating biologically active peptides at the feto-maternal interface. Among the various NEP substrates, several peptide growth factors and peptide hormones could be involved in trophoblastic proliferation and function. For example, $\mathrm{GnRH}$ and $\mathrm{GnRH}$ receptor were coexpressed in placental trophoblasts and $\mathrm{GnRH}$ induced hCG secretion from the trophoblasts via its receptor, indicating the paracrine/ autocrine regulation of hCG secretion by $\mathrm{GnRH}$ (Lin et al, 1995; Wolfahrt et al, 1998). ET-1 was produced and localized in the human trophoblasts (Malassine et al, 1993; Marinoni et al, 1995; Myatt et al, 1992) and ET-1 receptors were also present on the membranes of placental trophoblasts (Mondon et al, 1998; Rutherford et al, 1993), suggesting a paracrine or autocrine action of ET-1 in trophoblast function. Because NEP regulates the degradation and processing of bioactive peptides such as GnRH and ET-1 (Erdös and Skidgel, 1989; Flouret et al, 1987; Medeiros et al, 1991; Vijayaraghavan et al, 1990), it is speculated that NEP expressed on the surface of normal syncytiotrophoblast may play a role in the secretion of hCG or other trophoblastic functions by modulating the concentration and receptor binding of these peptides.

In the present study, we showed NEP/CD10 expression by immunohistochemistry, FACS, Western blotting, and enzyme assay in both choriocarcinoma cell lines and GTD tissues including hydatidiform mole, invasive mole, choriocarcinoma, and PSTT. The localization of NEP in GTDs has never been reported. Previous studies showed that NEP/CD10 was highly expressed on some leukemia and melanoma cell lines (Jongeneel et al, 1989) and hepatocellular carcinoma cell lines (Dragovic et al, 1994) with NEP enzyme activities. Variable levels of NEP expression and its catalytic activity were also reported in certain human tumor cell lines including lung cancer (Ganju et al, 1994; Shipp et al, 1991) and prostate cancer (Papandreou et al, 1998). Recent immunohistochemical study in 505 nonhematopoietic neoplasms has demonstrated that NEP/CD10 was frequently expressed in renal cell carcinoma (89\%), prostate carcinoma (61\%), transitional cell carcinoma (54\%), and endometrial stromal sarcoma (100\%) (Chu and Arber, 2000). On the other hand, our preliminary FACS study using gynecologic cancer cell lines showed that NEP was weakly expressed in only one endometrial cancer cell line, but not in six other cell lines including two derived from ovarian cancer, two from cervical cancer, and two from endometrial cancer (Ino et al, unpublished data). These findings suggest that only choriocarcinoma is a high NEP-expressing tumor among gynecologic malignancies, although the enzyme is expressed widely in neoplasms of the urinary tract.

Our immunoblotting analysis demonstrated NEP protein expression not only in choriocarcinoma cell lines, but also in tissue specimens from the normal placenta and GTD. Interestingly, NEP protein was detected as a double band of 95 and $100 \mathrm{kDa}$ in both the normal placenta and trophoblastic tumors. This was in agreement with one previous report indicating that normal placental NEP appeared as a double band with a molecular weight slightly higher than the $90 \mathrm{kDa}$ single band of the purified kidney NEP (Johnson et al, 1984). However, most previous studies demonstrated that NEP/CD10 was detected as a 90 to $110 \mathrm{kDa}$ single band in both normal and malignant cell types (Shipp and Look, 1993). Because NEP is a glycoprotein containing approximately $20 \%$ to $25 \%$ carbohydrate, there are tissue-specific differences in its molecular weight (Shipp and Look, 1993). Further, the molecular weight of placental NEP was reduced by neuraminidase treatment, suggesting that the NEP protein contains a large amount of sialic acid (Johnson et al, 1984). Lorkowski et al (1987) also demonstrated that the NEP precursor ( $88 \mathrm{kDa})$ in human fibroblasts was processed to a mature enzyme (94 kDa) containing sialylated oligosaccharides. These observations suggested that the double NEP band with different molecular weight observed in this study was probably due to the differential glycosylation of NEP molecules among the subsets of cyto-, syncytio-, and intermediate trophoblast, because all types of trophoblastic tumor other than PSTT are generally comprised of a heterogeneous mixture of these different cell populations (Kurman et al, 1984).

Our present data showed the differences in NEP/ CD10 expression and localization between the normal placenta and trophoblastic neoplasms. Invasive mole, which is considered to be intermediate between nonmalignant hydatidiform mole and truly malignant choriocarcinoma, contains hyperplastic trophoblasts with proliferative and invasive potential. We found that NEP was markedly expressed on syncytiotrophoblasts, but not on hyperplastic cytotrophoblasts in invasive mole tissues. In contrast, choriocarcinomas, which contain very anaplastic trophoblasts with highly invasive and metastatic potential, showed higher levels of NEP expression than hydatidiform and invasive moles. Furthermore, NEP was expressed not only on syncytiotrophoblastic choriocarcinoma cells, but also on invading cytotrophoblastic cells, although cytotrophoblasts in the noninvasive choriocarcinoma lesion showed no NEP expression. These findings suggest that NEP expression is increased and its localization is changed with advancement of aggressiveness in GTDs. PSTT is a very rare trophoblastic tumor predominantly composed of intermediate trophoblast that is generally benign but can be highly malignant (Kurman et al, 1984; Mazur and Kurman, 1987). Although only two cases of PSTT were examined in this study, we clearly demonstrated NEP/CD10 expression in neoplastic intermediate trophoblasts of PSTT.

Recent studies have shown that $\mathrm{GnRH}$, one of the NEP substrates, and its receptor are expressed in choriocarcinoma cell lines (Horvath et al, 1995; Yin et al, 1998), and $\mathrm{GnRH}$ is possibly involved in the hCG secretion of choriocarcinoma cells (Bützow, 1982; Shi et al, 1994). Interleukin-1 (IL-1), which can be degraded by NEP (Pierart et al, 1988), is also an important local regulator of hCG secretion by normal and 
malignant trophoblasts (Taniguchi et al, 1992; Yagel et al, 1989). In the present study, we demonstrated that NEP was localized in the syncytiotrophoblast subset in the normal placenta, hydatidiform mole, and invasive mole, while it was expressed in both syncytiotrophoblastic and cytotrophoblastic cells in the invading choriocarcinoma. Syncytiotrophoblasts are generally specialized for hCG production in the normal placenta and hydatidiform mole, but cytotrophoblasts can also produce hCG in choriocarcinoma (Kurman et al, 1984). Okamoto et al (1994) demonstrated that NEP effectively regulates the interaction of the peptide with its receptor only when the enzyme is colocalized in the same cell as the peptide receptor. Taken together, our results lead to the hypothesis that NEP colocalized with the receptors of $\mathrm{GnRH}$ and/or other hCGstimulatory mediators including $\mathrm{IL}-1$ may process these peptides (cytokines) and modulate their receptor binding, which may possibly contribute to the regulation and maintenance of $\mathrm{hCG}$ secretion from trophoblastic tumors. Further studies are required to clarify the interaction between NEP and the peptide substrates (and their receptors) on normal and neoplastic trophoblasts.

It has been demonstrated that a balance between biologically active (stimulatory or inhibitory) peptides and cell-surface peptidases might have regulatory effects on the behavior and function of certain malignancies (Shipp and Look, 1993). In this study, NEP/ CD10 over-expression was possibly correlated with malignant progression in trophoblastic tumors. Increased expression of NEP in hepatocellular carcinoma has also been reported to be correlated with malignant transformation (Dragovic et al, 1994). Similarly, over-expression of APN/CD13 was directly involved in tumor invasion of renal cell cancer and melanoma (Fujii et al, 1995; Saiki et al, 1993) or in tumor proliferation of choriocarcinoma (Ino et al, 1994). Our recent studies have shown the upregulated expression of APA in choriocarcinoma (Ino et al, 2000) and invasive cervical cancer (Fujimura et al, 2000). In contrast, decrease or loss of NEP/CD10 compared with normal cellular counterparts was reported in certain malignant tumors such as lung cancer (Cohen et al, 1996; Shipp et al, 1991) and prostate cancer (Papandreou et al, 1998). Dipeptidyl peptidase IV/CD26 was also down-regulated during melanoma progression (Wesley et al, 1999). Recently, Papandreou et al (1998) proposed two basic mechanisms of cell-surface peptidase involvement in the malignant process: (a) loss of function, resulting in an inability of the tumor cell to inactivate a stimulatory peptide; and (b) gain of function, resulting in the activation/processing of a stimulatory peptide or the inactivation of an inhibitory peptide, otherwise adjusting the concentration (activity) of peptide mediators available for receptor binding and signal transduction to the optimal conditions. The NEP over-expression in choriocarcinoma reported here may be due to the latter mechanism, by which NEP could contribute to the regulation of neoplastic trophoblast functions including hCG secretion. Thus, whether NEP as well as other membrane-bound peptidases is up-regulated or down-regulated with malignant transformation and tumor progression might be dependent on the tumorlineage or on the type of target peptide substrates (stimulatory or inhibitory).

In summary, hyperplastic and anaplastic trophoblasts from hydatidiform mole, invasive mole, choriocarcinoma, and PSTT expressed significant levels of NEP/CD10 and showed its differential localization among these GTDs. Investigations into the function of NEP on normal and malignant trophoblasts could be of help in gaining deeper insights into behavior and progression of GTDs.

\section{Materials and Methods}

\section{Cell Lines and Cell Culture}

Four human gestational choriocarcinoma cell lines were used. NaUCC-1, NaUCC-3, and NaUCC-4 were established and characterized in our laboratory (Ino et al, 1991; Sugiura et al, 1988). NaUCC-1 was derived from a brain metastasis of gestational choriocarcinoma and NaUCC-4 was derived from a lung metastasis, whereas NaUCC-3 was derived from a primary uterine choriocarcinoma lesion. BeWo was established by Pattillo and Gey (1968). All cell lines were maintained in either RPMI 1640 medium (Sigma Chemical Co., St. Louis, Missouri) or Dulbecco's modified eagle's medium (DMEM, Sigma) supplemented with $10 \%$ heat-inactivated fetal calf serum (FCS, JRH Biosciences, Lenexa, Kansas), penicillin (100 U/ml), and streptomycin $(100 \mu \mathrm{g} / \mathrm{ml})$ at $37^{\circ} \mathrm{C}$ in a humidified $5 \% \mathrm{CO}_{2}$ atmosphere.

\section{Tissues}

Twenty tissue specimens of gestational trophoblastic diseases (GTDs) were obtained from patients who were surgically treated at Nagoya University Hospital between 1990 and 1998. The specimens were classified based on their histopathological characteristics as complete hydatidiform mole $(n=6)$, invasive hydatidiform mole $(n=4)$, choriocarcinoma $(n=8)$, and placental site trophoblastic tumor (PSTT) $(n=2)$. None of the patients had prior chemotherapy for the disease before surgery with the exception of one PSTT case. In addition, 10 samples of normal placentas with different gestational ages ranging from 8-39 weeks were obtained from women who underwent therapeutic abortions or selective cesarean sections. All tissue samples were fixed in $10 \%$ formaldehyde, embedded in paraffin, and routinely stained with hematoxylin and eosin for histological examination. Some of the tissue samples were washed with phosphate-buffered saline (PBS) and snap frozen in liquid nitrogen immediately after removal, then stored at $-80^{\circ} \mathrm{C}$ until use for protein extraction. All samples were obtained according to the protocols approved by the Institutional Review Board (IRB) and the Ethics Committee of Nagoya University, School of Medicine. 


\section{Flow Cytometric Analysis}

Fluorescence-activated cell sorting (FACS) was performed to quantify NEP/CD10 expression on the choriocarcinoma cell surface. Cells in the logarithmic phase of cell growth were prepared at $1 \times 10^{6} / \mathrm{ml}$ in PBS and stained with phycoerythrin (PE)-conjugated anti-NEP/CD10 monoclonal antibody (mAb) (Pharmingen, San Diego, California) or PE-labeled isotypematched control mouse IgG (Coulter, Hialeah, Florida) for 1 hour at $4^{\circ} \mathrm{C}$. After three washes, cells were resuspended in PBS. FACS data were acquired on an FACS Calibur (Becton Dickinson, San Jose, California) and analyzed using CELLQuest software (Becton Dickinson). Dead cells and debris were excluded from analysis by the window set. Ten thousand cells were analyzed in one parameter mode. Each assay was performed three times.

\section{Assay for Enzymatic Activity of NEP}

Cell-surface NEP activity in each cell line was measured spectrophotometrically by a coupled assay as reported by Shipp et al (1989) and Papandreou et al (1998) with minor modifications. Briefly, whole cell suspensions $\left(5 \times 10^{5} / \mathrm{ml}\right)$ were prepared in $15 \mathrm{ml}$ test tubes by trypsinization from subconfluent cultures, washed with PBS, and resuspended in $1 \mathrm{ml}$ of prewarmed $1 \mathrm{~mm}$ succinyl-Ala-Ala-Phe- $p$-nitroanilide (Suc-Ala-Ala-Phe-pNA) (Bachem Bioscience Inc., King of Prussia, Pennsylvania) as a substrate in $0.1 \mathrm{M}$ Tris- $\mathrm{HCl}(\mathrm{pH} 7.6)$ in the presence of $10 \mu \mathrm{l}(20$ units/ml) porcine kidney aminopeptidase N (AP-N, Boehringer Mannheim, Indianapolis, Indiana). After vortex mixing, samples were incubated at $37^{\circ} \mathrm{C}$ with continuous agitation. In this coupled activity assay, NEP cleaves Suc-Ala-Ala-Phe-pNA between Ala and Phe, yielding Phe-pNA. AP-N subsequently cleaves Phe-pNA, generating $\mathrm{pNA}$ as the final product. At appropriate time points, the reaction was terminated by addition of two volumes of ice-cold PBS and the solution was collected. After centrifugation for 5 minutes at $4^{\circ} \mathrm{C}$, optical density of the supernatant at $405 \mathrm{~nm}$ was measured with a spectrophotometer (Multiskan Bichromatic, Labsystems, Helsinki, Finland). Cell-free (substrate alone or substrate with AP-N) and substrate-free blanks were run in parallel. All assays were conducted in triplicate and repeated three times. To confirm the specificity of the assay, in some experiments, cells were preincubated with the NEP inhibitor phosphoramidon (Peptide Institute, Osaka, Japan) at $2 \mu \mathrm{M}$ at $37^{\circ} \mathrm{C}$ for 10 minutes, followed by analysis as described above.

\section{Immunoblot Analysis}

The frozen tissue samples were homogenized with a motor-driven Teflon pestle for 10 minutes on ice in lysis buffer composed of $150 \mathrm{~mm} \mathrm{NaCl}, 20 \mathrm{~mm}$ Tris (pH7.5), 5 mm EDTA, 1\% Nonidet P-40 containing 1 $\mathrm{mm}$ phenylmethylsulfonyl fluoride, and $2 \mu \mathrm{g} / \mathrm{ml}$ aprotinin. Cellular protein lysates were also prepared from subconfluent culture in the same lysis buffer at $4^{\circ} \mathrm{C}$ for 30 minutes. Tissue extracts and cell lysates were cleared by centrifugation at $15,000 \times \mathrm{g}$ for 30 minutes at $4^{\circ} \mathrm{C}$ and stored at $-80^{\circ} \mathrm{C}$. Western blotting was carried out according to the method reported previously (Ino et al, 1994). Protein extract (30 $\mu \mathrm{g}$ ) was separated by SDS/7.5\% polyacrylamide gel electrophoresis (PAGE), transferred onto nitrocellulose membranes, and immunoblotted with the anti-NEP/CD10 mAb NCL-CD10-270 (clone 56C6, Novocastra Laboratories, Newcastle, United Kingdom) at a dilution of 1:50. The biotinylated secondary antibody (Vector Laboratories, Burlingame, California) was used at 1:200 dilution. Immunoreactive proteins were stained by the avidin-biotin-peroxidase complex method (Vector). SDS-PAGE prestained standard (Bio-Rad, Hemel Hempstead, United Kingdom) was used as a molecular mass marker. In negative control experiments, the primary antibody was replaced with normal mouse lgG.

\section{Immunohistochemistry}

Immunohistochemical staining was performed using the avidin-biotin immunoperoxidase technique. Sections were cut at a thickness of $4 \mu \mathrm{m}$. For antigen unmasking and epitope retrieval, deparaffinized sections in $0.01 \mathrm{M}$ citrate buffer were treated three times for 5 minutes at $90^{\circ} \mathrm{C}$ at $750 \mathrm{~W}$ with an $\mathrm{H} 2500$ microwave oven (M\&M, Tokyo, Japan). Endogenous peroxidase activity was blocked by incubation with $0.3 \% \mathrm{H}_{2} \mathrm{O}_{2}$ in methanol for 15 minutes, and nonspecific immunoglobulin binding was blocked by incubation with $10 \%$ normal goat serum in PBS for 10 minutes. The primary antibody (NCL-CD10-270, Novocastra) diluted in PBS (1:50) was added to the tissue sections and incubated overnight in a moist chamber at $4^{\circ} \mathrm{C}$. This newly developed $\mathrm{mAb}$ has been proved to be highly efficient for immunostaining of CD10 even in paraffin-embedded tissues after heat-induced epitope retrieval (Kaufmann et al, 1999; Mclntosh et al, 1999). The sections were rinsed with PBS and incubated for 30 minutes with biotinylated goat antimouse IgG (Nichirei, Tokyo, Japan) at a dilution of 1:300 at room temperature. After washes with PBS, the sections were incubated for 30 minutes with horseradish peroxidase-conjugated streptavidin (Histofine SAB-PO; Nichirei). Then the sections were treated with 3-amino-9-ethylcarbazole (AEC, Nichirei) as a chromogen in PBS containing $0.01 \% \mathrm{H}_{2} \mathrm{O}_{2}$ for 10 to 15 minutes. The slides were counterstained with Meyer's hematoxylin. As negative controls, the primary antibody was replaced with normal mouse $\lg G$ at an appropriate dilution. Staining intensity was estimated using an Olympus light microscope (Olympus Optical Company, Tokyo, Japan).

\section{References}

Burns DM, Walker B, Gray J, and Nelson J (1999). Breast cancer cell-associated endopeptidase EC 24.11 modulates proliferative response to bombesin. Br J Cancer 79:214-220. 
Bützow R (1982). Luteinizing hormone-releasing factor increases release of human chorionic gonadotrophin in isolated cell columns of normal and malignant trophoblasts. Int J Cancer 29:9-11.

Chu P and Arber DA (2000). Paraffin-section detection of CD10 in 505 nonhematopoietic neoplasms. Frequent expression in renal cell carcinoma and endometrial stromal sarcoma. Am J Clin Pathol 113: 374-382.

Cohen AJ, Bunn PA, Franklin W, Magill-Solc C, Hartmann C, Helfrich B, Gilman L, Folkvord J, Helm K, and Miller YE (1996). Neutral endopeptidase: Variable expression in human lung, inactivation in lung cancer, and modulation of peptideinduced calcium flux. Cancer Res 56:831-839.

Dragovic T, Deddish PA, Tan F, Weber G, and Erdös EG (1994). Increased expression of neprilysin (neutral endopeptidase 24.11) in rat and human hepatocellular carcinomas. Lab Invest 70:107-113.

Erdös EG and Skidgel RA (1989). Neutral endopeptidase 24.11 (enkephalinase) and related regulators of peptide hormones. FASEB J 3:145-151.

Flouret G, Majewski T, Peterson DR, Kenny AJ, and Carone FA (1987). Effects of D-amino acid substituents on degradation of LHRH analogues by proximal tubule. Am J Physiol 252:E320-E326.

Fujii H, Nakajima M, Saiki I, Yoneda J, Azuma I, and Tsuruo $T$ (1995). Human melanoma invasion and metastasis enhancement by high expression of aminopeptidase N/CD13. Clin Exp Metastasis 13:337-344.

Fujimura $\mathrm{H}$, Ino K, Nagasaka T, Nakashima N, Nakazato $\mathrm{H}$, Kikkawa F, and Mizutani S (2000). Aminopeptidase A expression in cervical neoplasia and its relationship to neoplastic transformation and progression. Oncology 58:342-352.

Ganju RK, Sunday M, Tsarwhas DG, Card A, and Shipp MA (1994). CD10/NEP in non-small cell lung carcinomas: Relationship to cellular proliferation. J Clin Invest 94:1784-1791.

Horvath JE, Ertl T, Qin Y, Groot K, and Schally AV (1995). $\mathrm{LH}-\mathrm{RH}$ and its antagonist Cetrorelix inhibit growth of JAR human choriocarcinoma cells in vitro. Int J Oncol 6:969-975.

Imai K, Kanzaki H, Fujiwara H, Maeda M, Ueda M, Suginami $\mathrm{H}$, and Mori $\mathrm{T}$ (1994). Expression and localization of aminopeptidase $\mathrm{N}$, neutral endopeptidase, and dipeptidyl peptidase IV in the human placenta and fetal membranes. Am J Obstet Gynecol 170:1163-1168.

Ino K, Goto S, Kosaki A, Nomura S, Asada E, Misawa T, Furuhashi Y, Mizutani S, and Tomoda Y (1991). Growth inhibitory effect of bestatin on choriocarcinoma cell lines in vitro. Biotherapy 3:351-357.

Ino K, Goto S, Okamoto T, Nomura S, Nawa A, Isobe K, Mizutani S, and Tomoda Y (1994). Expression of aminopeptidase $\mathrm{N}$ on human choriocarcinoma cells and cell growth suppression by the inhibition of aminopeptidase $\mathrm{N}$ activity. Jpn J Cancer Res 85:927-933.

Ino K, Nagasaka T, Okamoto T, Uehara C, Nakazato H, Nakashima N, and Mizutani S (2000). Expression of aminopeptidase $\mathrm{A}$ in human gestational choriocarcinoma cell lines and tissues. Placenta 21: 63-72.

Johnson AR, Skidgel RA, Gafford JT, and Erdös EG (1984). Enzymes in placental microvilli: Angiotensin I converting enzyme, angiotensinase $A$, carboxypeptidase, and neutral endopeptidase (“enkephalinase"). Peptides 5:789-796.
Jongeneel CV, Quackenbush EJ, Ronco P, Verroust P, Carrel $S$, and Letarte M (1989). Common acute lymphoblastic leukemia antigen expressed on leukemia and melanoma cell lines has neutral endopeptidase activity. J Clin Invest 83: 713-717.

Kaufmann O, Flath B, Späth-Schwalbe E, Possinger K, and Dietel M (1999). Immunohistochemical detection of CD10 with monoclonal antibody 56C6 on paraffin sections. Am J Clin Pathol 111:117-122.

Kurman RJ, Young RH, Norris HJ, Main CS, Lawrence WD, and Scully RE (1984). Immunocytochemical localization of placental lactogen and chorionic gonadotropin in the normal placenta and trophoblastic tumors, with emphasis on intermediate trophoblast and the placental site trophoblastic tumor. Int J Gynecol Pathol 3:101-121.

Li XM, Moutquin JM, Deschenes J, Bourque L, Marois M, and Forest JC (1995). Increased immunohistochemical expression of neutral metalloendopeptidase (enkephalinase; EC 3.4.24.11) in villi of the human placenta with pre-eclampsia. Placenta 16:435-445.

Lin L-S, Roberts VJ, and Yen SS (1995). Expression of human gonadotropin-releasing hormone receptor gene in the placenta and its functional relationship to human chorionic gonadotropin secretion. J Clin Endocrinol Metab 80:580585.

Lorkowski G, Zijderhand-Bleekemolen JE, Erdös EG, Figura KV, and Hasilik A (1987). Neutral endopeptidase-24.11 (enkephalinase): Biosynthesis and localization in human fibroblasts. Biochem J 248:345-350.

Malassine A, Cronier L, Mondon F, Mignot TM, and Ferre F (1993). Localization and production of immunoreactive endothelin-1 in the trophoblast of human placenta. Cell Tissue Res 271:491-497.

Malfroy B, Kuang W-J, Seeburg PH, Mason AJ, and Schofield PR (1988). Molecular cloning and amino acid sequence of human enkephalinase (neutral endopeptidase). FEBS Letts 229:206-210.

Marinoni E, Picca A, Scucchi L, Cosmi EV, and Di-lorio R (1995). Immunohistochemical localization of endothelin-1 in placenta and fetal membranes in term and preterm human pregnancy. Am J Reprod Immunol 34:213-218.

Mazur MT and Kurman RJ (1987). Choriocarcinoma and placental site trophoblastic tumor. In: Szulman AE and Buchsbaum HJ, editors. Gestational trophoblastic disease. New York: Springer-Verlag, 45-68.

Mclntosh GG, Lodge AJ, Watson P, Hall AG, Wood K, Anderson JJ, Angus B, Horne CHW, and Milton ID (1999). NCL-CD10-270: A new monoclonal antibody recognizing CD10 in paraffin-embedded tissue. Am J Pathol 154:77-82.

Medeiros MDS, Turner AJ, Ljungqvist $\mathrm{A}$, and Folkers $\mathrm{K}$ (1991). Metabolic stability of the LHRH antagonist antide to cell-surface peptidase. Biochem Biophys Res Commun 176: 25-30.

Mondon F, Anouar A, and Ferre F (1998). Endothelin receptor subtypes in the microvillous trophoblastic membrane of early gestation and term human placentas. Eur J Endocrinol 139: 231-237.

Myatt L, Brewer AS, and Brockman DE (1992). The comparative effects of big endothelin-1, endothelin-1, and endothelin-3 in the human fetal-placental circulation. Am J Obstet Gynecol 167:1651-1656. 
Okamoto A, Lovett M, Payan DG, and Bunnett NW (1994). Interactions between neutral endopeptidase (EC 3.4.24.11) and the substance $P$ (NK1) receptor expressed in mammalian cells. Biochem J 299:683-693.

Papandreou CN, Usmani B, Geng Y, Bogenrieder T, Freeman R, Wilk S, Finstad CL, Reuter VE, Powell CT, Scheinberg D, Magill C, Scher HI, Albino AP, and Nanus DM (1998). Neutral endopeptidase 24.11 loss in metastatic human prostate cancer contributes to androgen-independent progression. Nat Med 4:50-57.

Pattillo RA and Gey GO (1968). The establishment of a cell line of human hormone-synthesizing trophoblastic cells in vitro. Cancer Res 28:1231-1236.

Pierart ME, Najdovski T, Appelboom TE, and DeschodtLanckman MM (1988). Effect of human endopeptidase 24.11 ("enkephalinase") on IL-1-induced thymocyte proliferation activity. J Immunol 140:3808-3811.

Rutherford RAD, Warton J, McCarthy A, Gordon L, Sullivan MHF, Elder MG, and Polak JM (1993). Differential localization of endothelin ETA and ETB binding sites in human placenta. Br J Pharmacol 109:544-552.

Saiki I, Fujii H, Yoneda J, Abe F, Nakajima M, Tsuruo T, and Azuma I (1993). Role of aminopeptidase N (CD13) in tumorcell invasion and extracellular matrix degradation. Int J Cancer 54:137-143.

Shi LY, Zhang ZW, and Li WX (1994). Regulation of human chorionic gonadotropin secretion and messenger ribonucleic acid levels by Follistatin in the NUCC- 3 choriocarcinoma cell line. Endocrinol 134:2431-2437.

Shih IM, Mazur MT, and Kurman RJ (1999). Chapter 49: Gestational trophoblastic disease. In: Sternberg SS, editor. Diagnostic Surgical Pathology. Third Edition. New York: Lippincott, Williams \& Wilkins, 2067-2086.

Shipp MA and Look AT (1993). Hematopoietic differentiation antigens that are membrane-associated enzymes: Cutting is the key! Blood 82:1052-1070.

Shipp MA, Tarr GE, Chen C-Y, Switzer SN, Hersh LB, Stein $H$, Sunday ME, and Reinherz EL (1991). CD10/neutral endopeptidase 24.11 hydrolyzes bombesin-like peptides and regulates the growth of small cell carcinomas of the lung. Proc Natl Acad Sci USA 88:10662-10666.
Shipp MA, Vijayaraghavan J, Schmidt EV, Masteller EL, D'Adamio L, Hersh LB, and Reinherz EL (1989). Common acute lymphoblastic leukemia antigen (CALLA) is active neutral endopeptidase 24.11 ("enkephalinase"): Direct evidence by cDNA transfection analysis. Proc Natl Acad Sci USA 86:297-301.

Sugiura M, Goto S, Saito M, Kato S, Hattori S, and Tomoda $Y$ (1988). Establishment and characterization of three new human gestational choriocarcinoma cell lines. Acta Obst Gynaecol Jpn 40:1447-1454.

Taniguchi T, Matsuzaki N, Jo T, Saji F, Taga T, Hirano T, Kishimoto T, and Tanizawa O (1992). Interleukin-1 (IL-1)induced IL-6- and IL-6-receptor-mediated release of human chorionic gonadotropin by choriocarcinoma cell lines (Jar and HCCM-5) activates adenosine 3', 5'-monophosphateindependent signal transduction pathway. J Clin Endocrinol Metab 74:1389-1395.

Vijayaraghavan J, Scicli AG, Carretero OA, Slaughter C, Moomaw C, and Hersh LB (1990). The hydrolysis of endothelins by neutral endopeptidase 24.11 (enkephalinase). J Biol Chem 265:14150-14155.

Wesley UV, Albino AP, Tiwari S, and Houghton AN (1999). A role for dipeptidyl peptidase IV in suppressing the malignant phenotype of melanocytic cells. J Exp Med 190:311-322.

Wolfahrt S, Kleine B, and Rossmanith WG (1998). Detection of gonadotrophin releasing hormone and its receptor mRNA in human placental trophoblasts using in-situ reverse transcription-polymerase chain reaction. Mol Human Reprod 4:999-1006.

Yagel S, Lala PK, Powell WA, and Casper RF (1989). Interleukin-1 stimulates human chorionic gonadotropin secretion by first trimester human trophoblast. J Clin Endocrinol Metab 68:992-995.

Yin $\mathrm{H}$, Cheng KW, Hwa HL, Peng C, Auersperg N, and Leung PCK (1998). Expression of the messenger RNA for gonadotropin-releasing hormone and its receptor in human cancer cell lines. Life Sci 62:2015-2023. 